NASZA DERMATOLOGIA Online OUR DERMATOLOGY Online

Source of Support: Nil

Competing Interests: None declared

\section{MEDICAL EPONYMS LINKED TO HAIR}

\author{
Khalid Al Aboud
}

Pathology Department, Wake Forest University, Winston-Salem, NC, USA

Corresponding author: Dr. Khalid Al Aboud

amoa65@hotmail.com
An eponym is a word derived from the name of a person, whether real or fictional. A medical eponym is thus any word related to medicine, whose name is derived from a person.

Nevertheless, some ancient medical scientists who made researches and their names were linked to medical conditions, hence become „eponyms” are now ,anonyms”, in the sense that little is known about them.

In Table I [1-12], I listed some commonly used medical eponyms which are primarily linked to hair.

As it is seen from the table, the ,hair eponyms" are not limited to the hair disorders but also, the anatomical structures, inside the hair follicle.

Tracing the historical origins of medical eponyms can be fraught with dilemmas, particularly when the evidence for the naming comes from portraiture, as in Queen Anne's sign [12].

There is a rise and fall in the usage of eponyms in medical literature as there is ongoing dispute whether to use or not to use them. However, it is obvious that those eponyms coined for any old and common medical conditions, are likely to be continually used.

\section{REFERENCES}

1. Steffen C: Dermatopathology in historical perspective: the man behind the eponym: Horatio George Adamson and Adamson's fringe. Am J Dermatopathol. 2001;23:485-8.

2. Mirmirani P, Huang KP, Price VH: A practical, algorithmic approach to diagnosing hair shaft disorders. Int $\mathrm{J}$ Dermatol 2011;50:1-12.

3. Carvajal-Huerta L: Epidermolytic palmoplantar keratoderma with woolly hair and dilated cardiomyopathy. J Am Acad Dermatol. 1998;39:418-21.

4. Protonotarios N, Tsatsopoulou A, Patsourakos P, Alexopoulos D, Gezerlis P, Simitsis S, et al: Cardiac abnormalities in familial palmoplantar keratosis. Br Heart J. 1986;56:321-6.

5. Steffen C: The man behind the eponym: Jacob Henle--Henle's layer of the internal root sheath. Am J Dermatopathol. 2001;23:54951.

6. Steffen C:The man behind the eponym: Thomas Henry Huxley: Huxley's layer of the inner root sheath. Am J Dermatopathol. 2002;24:82-4.

7. Srivastava M, Mikkilineni R, Konstadt J: Lassueur-GrahamLittle-Piccardi syndrome. Dermatol Online J. 2007;13:12.

8. Prasad AN, Levin S, Rupar CA, Prasad C: Menkes disease and infantile epilepsy. Brain Dev. 2011;33:866-76.

9. Menkes JH, Alter M, Steigleder GK, Weakly DR, Sung Jho: A sex-linked recessive disorder with retardation of growth, peculiar hair, and focal cerebral and cerebellar degeneration. Pediatrics, Evanston, Illinois. 1962,29:764-79.

10. Netherton EW: A unique case of trichorrhexis nodosa; bamboo hairs. AMA Arch Derm. 1958;78:483-7.

11. Lane Furdell E: Eponymous, anonymous: Queen Anne's sign and the misnaming of a symptom. J Med Biogr. 2007;15:97-101. 12. Keynes M: Letter to the editor. J Med Biogr. 2009;17:62. 


\begin{tabular}{|c|c|}
\hline Medical eponyms linked to hair & Remarks \\
\hline Adamson's fringe & $\begin{array}{l}\text { In growing hairs, the margin between the mitotically active hair bulb and the } \\
\text { inactive hair shaft is known as Adamson's fringe [1]. It is named after, Horatio } \\
\text { George Adamson (1866-1955). }\end{array}$ \\
\hline Björnstad syndrome & $\begin{array}{l}\text { It is an autosomal recessive disorder associated with sensorineural hearing loss and } \\
\text { pili torti [2]. It was first characterized in 1965, in Oslo, by Prof. Roar Theodor } \\
\text { Bjørnstad (1908-2002). }\end{array}$ \\
\hline Carvajal syndrome & $\begin{array}{l}\text { Carvajal syndrome (CS) (also known as "Striate palmoplantar keratoderma with } \\
\text { woolly hair and cardiomyopathy" and "Striate palmoplantar keratoderma with } \\
\text { woolly hair and left ventricular dilated cardiomyopathy,". Carvajal-Huerta } \\
\text { (1998) described } 18 \text { patients with a confirmation of epidermolytic palmoplantar } \\
\text { keratoderma, woolly hair, and dilated cardiomyopathy, examined clinically and } \\
\text { histologically in Ecuador between } 1970 \text { and } 1997 \text { [3]. CS might be a variant of } \\
\text { Naxos disease (ND), which was first described by Protonotarios et al., in families } \\
\text { originating from the Greek island of Naxos [4]. ND is a rare autosomal recessive } \\
\text { inherited association of right ventricular dysplasia/dilated cardiomyopathy with } \\
\text { woolly hair and palmoplantar keratoderma. }\end{array}$ \\
\hline $\begin{array}{c}\text { Henle's Layer of the Internal } \\
\text { Root Sheath }\end{array}$ & It is named after, Jacob Henle (1809-1885) [5]. \\
\hline $\begin{array}{l}\text { Huxley Huxley's Layer of the } \\
\text { Inner Root Sheath }\end{array}$ & It is named after, Thomas Henry Huxley (1825-1895) [6]. \\
\hline $\begin{array}{l}\text { Graham-Little-Piccardi-Lasseur } \\
\text { syndrome }\end{array}$ & $\begin{array}{l}\text { Also, called as Lassueur-Graham-Little-Piccardi syndrome or Piccardi-Graham } \\
\text { Little-Lasseur syndrome. It is a rare lichenoid dermatosis defined by the triad of } \\
\text { multifocal cicatricial alopecia of the scalp; noncicatricial alopecia of the axilla and } \\
\text { groin; and a follicular lichen planus eruption on the body, scalp, or both. It was } \\
\text { initially described by Piccardi in 1913. In 1915, Sir Ernest Graham-Little (1867- } \\
\text { 1950) published a similar case observed by Lassueur. Since then several case } \\
\text { reports of this syndrome have been published [7]. }\end{array}$ \\
\hline Menkes disease (MD) & $\begin{array}{l}\text { Also, known as, Menkes' kinky hair syndrome is a multisystemic lethal disorder } \\
\text { due to impaired copper transport and metabolism with pili torti [8]. Menkes and } \\
\text { collaborators defined the syndrome in } 1962 \text { on the basis of five boys in the same } \\
\text { family. John Hans Menkes, was Austrian-American paediatrician and writer, born } \\
1928 \text {. }\end{array}$ \\
\hline Netherton syndrome (NS) & $\begin{array}{l}\text { NS is characterized by the triad of trichorrhexis invaginata, ichthyosis linearis } \\
\text { circumflexa, and an atopic diathesis [10]. It is named after E. W. Netherton. Who } \\
\text { described a 4-year old girl with scaly red and different hair, which he called } \\
\text { bamboo hair, because of how it looked in the microscope. Nine years earlier, the Italian } \\
\text { dermatologist Come described a condition in a young woman with a ring } \\
\text { shape change in her skin, which he called itcthyosis Linearis circumflex. These two } \\
\text { descriptions were considered to be related. }\end{array}$ \\
\hline Queen Anne's sign & $\begin{array}{l}\text { It is also known as, the sign of Hertoghe. It is a laterally truncated eyebrow, and } \\
\text { is a sign of hypothyroidism. The sign is named for Eugene Hertoghe of Antwerp, } \\
\text { a pioneer in thyroid function research. The eponym is disputed by some and the } \\
\text { association with Anne of Denmark is based on portraiture, and history does not } \\
\text { suggest that she suffered hypothyroidism }[11,12] \text {. }\end{array}$ \\
\hline
\end{tabular}

Copyright by Khalid Al Aboud. This is an open access article distributed under the terms of the Creative Commons Attribution License, which permits unrestricted use, distribution, and reproduction in any medium, provided the original author and source are credited. 